\title{
REIMAGINING FUTURE ISLAND: \\ The COVID-I9 Impacts on Tourism Sector in Small Island Developing States (SIDS) and Strategies to Moving Forward
}

\author{
Abdul Fikri Angga Reksa, Ayu Nova Lissandhi, Choerunisa Noor Syahid \\ Research Center for Area Studies \\ Indonesian Institute of Sciences, Jakarta, Indonesia \\ Corresponding Author Email: fikrianggareksa@gmail.com
}

\begin{abstract}
The COVID-I9 pandemic has ravaged the global tourism industry, leaving millions of people unemployed without certainty when tourism bounces back. Small Island Developing States (SIDS) are amongst the worst hit by the novel coronavirus. The unprecedented crisis has severely aggravated the SIDS economic growth due to relying on foreign tourists heavily. In the absence of international tourism, small island residents have been grappling with alternative income sources. Despite its notorious impacts, many scholars look at this global pandemic as a discernible opportunity to reverse mass tourism in the SIDS. Therefore, this paper aims to elaborate on the current condition of small islands communities amid COVID-I9, their coping strategies, and their reflection of the future tourism industry in the SIDS. Furthermore, this paper also aims to discuss a prevailing policy to contain health emergency and economic collapse in the SIDS. Based on the critical literature review, many SIDS were already faced complex predicaments before the pandemic, such as high vulnerability to the climate crisis, lack of natural resources, extreme poverty, and reliance on external debts. International support is crucial to avoid the worst-case scenario for SIDS, including those which depend on the tourism industry. As a part of the recovery phase, this paper underscores the urgency of a more sustainable tourism practice for future development in the SIDS. That comprises strategic issues ranging from environmental-based tourism with a focus on socio-cultural aspects, and economic diversification to small island community resilience.
\end{abstract}

Keywords: COVID-I9; Small Island Developing States; sustainable tourism; community resilience

\begin{abstract}
Abstrak
Pandemi COVID-I9 telah memporak-porandakan industri pariwisata global, menyebabkan jutaan orang kehilangan pekerjaan tanpa kepastian pariwisata akan pulih kembali. Negara Kepulauan Kecil dan Berkembang (SIDS) terdampak paling parah oleh virus korona baru. Krisis yang belum pernah terjadi sebelumnya telah memperparah kondisi ekonomi SIDS lantaran ketergantungannya pada pemasukan dari turis asing. Dalam ketiadaan pariwisata internasional, banyak penduduk pulau bersusah payah mencari mata pencaharian yang baru. Kendati banyak dampak buruk yang dialami, para akademisi menilai pandemi ini sebagai kesempatan yang nyata untuk memikirkan ulang pariwisata massal di SIDS. Karena itu, tulisan ini bertujuan untuk mengelaborasi tentang kondisi terkini masyarakat pulau-pulau kecil pada masa COVID-I9, strategi penanggulangan, dan refleksi mereka terhadap industri pariwisata masa depan di SIDS. Lebih lanjut, tulisan ini juga bertujuan untuk membahas kebijakan yang berlaku untuk mengatasi darurat kesehatan dan keruntuhan ekonomi di SIDS. Berdasarkan tinjauan literatur kritis, banyak SIDS telah menghadapi kesulitan yang kompleks sebelum pandemi, seperti kerentanan tinggi terha-
\end{abstract}


dap krisis iklim, kurangnya sumber daya alam, kemiskinan ekstrim, dan ketergantungan pada hutang luar negeri. Dukungan internasional sangat penting untuk menghindari skenario terburuk untuk SIDS, termasuk negara yang bergantung pada industri pariwisata. Sebagai bagian dari fase pemulihan, makalah ini menggarisbawahi urgensi dari praktik pariwisata yang lebih berkelanjutan untuk pengembangan SIDS di masa mendatang. Hal itu termasuk membahas isu-isu strategis mulai dari pariwisata berbasis lingkungan dengan penekanan pada aspek sosio-kultur, diversifikasi ekonomi hingga memperkuat ketahanan masyarakat di negara kepulauan kecil.

Kata Kunci: COVID-I9; Negara Kepulauan Kecil dan Berkembang; pariwisata berkelanjutan; daya lenting komunitas

\section{INTRODUCTION}

The COVID-I9 pandemic has not only disrupted the global health system but also almost all critical sectors. Until the end of March 202I, COVID-I9 has infected more than I30 million people and resulted in 2,8 million deaths (Worldometers.info, 202I). This number is predicted to escalate, albeit many countries have been executing the vaccination process. Since the beginning of the pandemic, many countries have applied some prevention measures to reduce its notorious impacts. To contain the onset widespread of the novel coronavirus, the government worldwide have limited mobility through a lockdown policy (e.g., suspension of international flights). Consequently, it has created havoc in the global economy since most countries are not fully prepared for this unprecedented circumstance. It is also recognized as the worst economic crisis that caused a recession and even economic depression for some countries (McKibbin \& Fernando, 2020).

Small Island Developing States (SIDS) are increasingly vulnerable to the social and economic impacts of the COVID-I9 crisis. Remarkably, the tourism sector is one of the financial backbones for many SIDS. World Tourism Organization/UNWTO (202ob) reveals the tourism industry accounts for more than $30 \%$ to $80 \%$ of total exports in most SIDS in the Caribbean and Pacific. It also shares more than $20 \%$ of the direct employment in the Caribbean and Latin America. However, the high percentage of tourism economic contribution actually does not represent the majority of small island community income, which still considered very low (Pratt, 20I5). Therefore, since the major shock occurred last year, small island communities have been struggling from adverse socio-economic impacts up to now. Overall, their GDP dropped by $6.9 \%$; the percentage is higher in comparison to other developing countries GDP average, which fell by $4.8 \%$ in 2020 (OECD, 202I). While tourism is one of the most labor-intensive sectors in the SIDS, thousands of people have already lost their jobs without any social safety net (Connell, 202I).

The specific geographical condition has been another challenge in many SIDS. Limited arable land, lack of natural resources, and the vulnerability to climate disasters have hampered the development process in SIDS, taking people to be left behind (Kelman, 20I4). Many island residents have no various livelihood option to retain their lives, other than ocean-based economies and coastal tourism. On top of that, the underlying political factors play a significant role in marginalizing island communities, including lack of local voices in every development process and problematic narrative to SIDS community (Campling 2006; Kelman, 2010). Thus, it is quite evident that the SIDS challenges are very complex and systematically embedded in all aspects, even before COVID-I9 occurred. Hence, within a bewildering crisis and health emergencies like the pandemic, the SIDS has received enormous concern from the international organizations.

Some studies have undertaken to comprehend the impact of COVID-I9 in SIDS generally. OECD (2020) mentions the SIDS have successfully contained health consequences so far, but still scrambling against economic decay. Nevertheless, the COVID-I9 spread rate and the undetected case might be higher, becoming a sort of reminder in the reopening borders regulation (Leal Filho et al., 2020). With many countries economically dependent 
on international tourism, economic recovery measures should address the health infrastructure as an integral part of future development policy (Murphy et al., 2020).

Apart from that, a strong narrative towards a more sustainable pathway in the tourism sector has been emerging during the pandemic (OECD, 2020). However, several technical questions on how to achieve it remains. First, what strategies could be better implemented in a tourism recovery in the SIDS. Scholars have revealed that tourism may be the last to recover after COVID-I9 (Zhang et al., 202I). Second, how to integrate a recovery phase in tourism sectors and development program, e.g., poverty reduction and land development planning.

Although the impact of COVID-I9 has been widely studied, discussions about the future of SIDS post-COVID-I9 are still limited. Hence this paper will discuss ongoing narratives for the future development in some SIDS countries, especially local narratives. Understanding local narratives is essential to comprehend relationality and its context thoroughly. This paper also attempts to provide various COVID-I9 countermeasures in the SIDS and how that will change community perspective towards the tourism industry. To achieve the main purposes of this paper, it rests on the following research questions: (I) How has COVID-I9 impacted SIDS countries?; (2) How are local coping strategies as well as global responses to tackle COVID-I9 in the tourism industry?; (3) How does SIDS community reimagine the future tourism industry in their home country?

To limit the scope of the discussion, the qualitative approach using case study methods were employed. A case study method allows researchers to answer "why" and "how" questions, investigated in context, examined in its real-world setting (Yin, 2013). Hence, it can capture diverse nuances and more inherent components in one occurrence comprehensively. The explorative literature review in Google Scholar was applied to comprehend the case study. Apart from that, the grey literature review was conducted to complement the findings.
Nevertheless, this method remains some limitations, such as the quality of the search process, time constraints, and access to the paper and data. This paper focuses on two SIDS countries with a high dependency on the tourism sector based on OECD (2020), namely, Maldives and Fiji. The rationale behind those selected countries also considering the high-level impact of pandemics. Besides Maldives and Fiji, this study also showcases several countries such as Aruba, Belize, Saint Lucia, and Samoa to compare both in effects, coping strategies, and future development. This study provides preliminary findings on the current state of research in SIDS concerning the COVID-I9 pandemic that valuable for future research topic.

\section{OVERVIEW OF SIDS AND SEVERAL CHALLENGES}

Based on the United Nations Department of Economic and Social Affairs (2020), the geographical location of SIDS is divided into three regions: the Caribbean, the Pacific, and AIMS (Atlantic, Indian Ocean, Mediterranean, and the South China Sea). There are 58 countries in total, and eight of them are also least developed countries (Comoros, Kiribati, Tuvalu, Timor-Leste, Solomon Islands, Haiti, SaoTome, and Principe, Guinea-Bissau). The most common characteristic is: "small size, with implications for pressure on resources and limited economic diversity; remoteness and isolation, leading to challenges for trading but also to a unique biodiversity and cultural richness; and a maritime environment, leading to strong tourism assets but vulnerability to climate change" (UNWTO, 2020). Since I992, the SIDS has become a particular case for both environment and development pathways. The SIDS have been facing complex environmental conditions and deeply connected with the climate crisis narratives (Pratt, 2015).

There are several development buzzwords embedded in the SIDS, mostly enacted by the international development agencies. As a list of countries relying on the tourism sector, sustainability has been the fundamental requisite to protect the island. However, the implemen- 
tation is still insufficient. Many studies recommend the sustainable tourism framework which emphasizes nature tourism as a landscape of attraction and as a natural barrier to reduce the impact of climate crisis as well as biodiversity protection (de-Miguel-Molinna, et al., 2014). However, that measure is wellknown as costly and hence it is need development agency intervention to objectify it.

Another salient challenge is the narrative of the community in the SIDS vulnerability itself. Kelman (20I8) discusses the terminology "islandness" as an indicator of the high degree of vulnerability in the SIDS. That paper underscores the importance of understanding the island community as a whole system. It is an undeniable fact that the island community is vulnerable, but they also resilient. Therefore, community involvement in the development project including sustainable tourism is imperative. It also applies to address environmental problem in SIDS. Apart from integrative governance, community resilience is considered as the key solutions (Gheuens et al, 20I9). All in all, the acknowledgement of socio-cultural aspects should be included in the development framework.

Petzol and Ratter (2019) corroborate the significance of socio-cultural aspects to tackle SIDS environmental issues, such as adaptation to climate crisis projects. So, the development strategy will not only be based on technological approaches such as the blue economy and green economy. The intricacies of socio-cultural aspects have been evident within the COVID-I9 crisis that caused myriad impacts. However, the pandemic is also a portal to SIDS. The most central question is whether the pandemic is a portal to a more resilient community or conversely.

\section{RESULTS AND DISCUSSION}

In order to organize some structured discussions, the remainder of the results part in this paper is constructed as follows. The following part presents the COVID-I9 socio-economic impacts in SIDS and the fall down of the tourism industry. Next, it explains some coping strategies and response capacity of the com- munity to the government level. The discussion part elaborates on the future tourism industry in the SIDS, portraying case study from several countries. Lastly, this paper provides a critical reflection on sustainable tourism that accounts for the planet, people, and profit.

\section{SOCIO-ECONOMIC IMPACT OF COVID-19 CRISIS}

Tourism is among the most affected sectors by the pandemic. International tourism is predicted to decline over $70 \%$, with the total losses of US\$ 935 billion in export revenues only from foreign tourists last year (UNWTO, 2020). In the SIDS, some countries have experienced an economic depression. Even though the majority of SIDS are not categorized as a poor country, most of them share environmental vulnerability, limited healthcare provision, and an ageing population (Suzana et al., 2018). The novel coronavirus outbreak has been putting small island residents at high risk. Mainly most of them have not prepared for alternative income sources and social safety net in the extended period.

Based on United Nations Conference on Trade and Development (UNCTAD), I3 out of 29 SIDS countries predicted to lose more than IO\% of their GDP. The situation is compounded by tourism dependency and the external debt they endure. For instance, the Maldives, SIDS member which most prominent for exquisite coastal landscapes and marine biodiversity. Tourism in the Maldives contributes roughly $60 \%$ of the total GDP. The Maldives is estimated to fall in GDP around $17 \%$, the highest among SIDS. Thus, official development assistance (ODA) for the Maldives could reach up to US\$I,II5O. Not to mention that the Maldives have also trapped in external debts around $40 \%$ of their GDP. At the same time, Fiji is slightly fortunate, though it is expected to fall in GDP by around ro \%. Fiji has fewer external debt than some others SIDS. Nevertheless, it is significant to promote funding at zero interest rates and defer recent debt payments for the SIDS (Coke-Hamilton, 2020). 
Figure I. Economic impacts of COVID-I9 in SIDS

\begin{tabular}{|c|c|c|c|c|c|}
\hline & $\begin{array}{l}\text { Tourism } \\
(\% \\
\text { GDP) }\end{array}$ & $\begin{array}{l}\text { External } \\
\text { Debt (\% } \\
\text { GDP) }\end{array}$ & $\begin{array}{c}\text { Reserves } \\
\text { (no of } \\
\text { months } \\
\text { of } \\
\text { imports) }\end{array}$ & $\begin{array}{l}\text { Estimated } \\
\text { Fall in } \\
\text { GDP }(\%)\end{array}$ & $\begin{array}{c}\text { Financial } \\
\text { Assistance } \\
\text { Needed } \\
\text { (million } \\
\text { USD) }\end{array}$ \\
\hline - Maldives & 66 & 48 & 2 & $17 \%$ & 1,150 \\
\hline 4 seychelles & 66 & 198 & 3 & $16 \%$ & 153 \\
\hline $\begin{array}{l}\text { - St. Kitts and } \\
\text { Nevis }\end{array}$ & 63 & | 20 & 6 & $16 \%$ & 92 \\
\hline Grenada & 56 & 59 & 4 & $14 \%$ & 137 \\
\hline Vanuatu & 48 & 46 & 10 & $12 \%$ & 81 \\
\hline Cabo Verde & 46 & 89 & 5 & $12 \%$ & 131 \\
\hline $\begin{array}{l}\text { 6) St. Vincent and } \\
\text { the Grenadines }\end{array}$ & 46 & 38 & 4 & $12 \%$ & 60 \\
\hline $\begin{array}{l}\Theta \text { Antigua and } \\
\text { Barbuda }\end{array}$ & 45 & 34 & 3 & $11 \%$ & 243 \\
\hline A St. Lucia & $\square_{43}$ & 35 & 3 & $11 \%$ & 250 \\
\hline Palau & $\square_{43}$ & | 31 & na & $11 \%$ & 31 \\
\hline - Bahamas, The & $\square_{40}$ & 194 & 3 & $10 \%$ & 846 \\
\hline O Fiil & $\square_{40}$ & | 17 & 3 & $10 \%$ & 343 \\
\hline * Dominica & $\square_{38}$ & 55 & 5 & $10 \%$ & 28 \\
\hline $\boldsymbol{\theta}$ Barbados & $\square_{36}$ & 29 & 3 & $9 \%$ & 369 \\
\hline Q Jamaica & $\square_{35}$ & 108 & 5 & $9 \%$ & 775 \\
\hline $\begin{array}{l}\text { E) Sao Tome and } \\
\text { Principe }\end{array}$ & $\square^{27}$ & 59 & 3 & $7 \%$ & 25 \\
\hline Mauritius & 24 & 72 & 5 & $6 \%$ & 540 \\
\hline Samoa & 23 & 51 & 4 & $6 \%$ & 48 \\
\hline Tonga & 21 & 41 & 8 & $5 \%$ & 12 \\
\hline Kiribati & 19 & 8 & na & $5 \%$ & 1 \\
\hline $\begin{array}{l}\text { Solomon } \\
\text { Istands }\end{array}$ & D13 & 29 & 9 & $3 \%$ & 23 \\
\hline Comoros & 10 & | 17 & 7 & $3 \%$ & 19 \\
\hline $\begin{array}{l}\text { E Marshall } \\
\text { lstands }\end{array}$ & |9 & 52 & na & $2 \%$ & 5 \\
\hline $\begin{array}{l}\text { Micronesia, Fed. } \\
\text { Sts. }\end{array}$ & |8 & 29 & 5 & $2 \%$ & 6 \\
\hline $\begin{array}{l}\text { Trinidad and } \\
\text { Tobago }\end{array}$ & |8 & | 30 & 9 & $2 \%$ & 135 \\
\hline Tuvalu & 16 & 45 & na & $2 \%$ & 1 \\
\hline (2) Timor-Leste & $\mid 3$ & $\mid 7$ & 7 & $1 \%$ & 20 \\
\hline Nauru & | 1 & $\mid 22$ & na & $0 \%$ & 0 \\
\hline TOTAL SIDS & 29 & 72 & 6 & $7 \%$ & 5,523 \\
\hline
\end{tabular}

Source: UNCTAD, 2020.

Based on United Nations Conference on Trade and Development (UNCTAD), I3 out of 29 SIDS countries predicted to lose more than IO\% of their GDP. The situation is compounded by tourism dependency and the external debt they endure. For instance, the Maldives, SIDS member which most prominent for exquisite coastal landscapes and marine biodiversity. Tourism in the Maldives contributes roughly $60 \%$ of the total GDP. The Maldives is estimated to fall in GDP around $17 \%$, the highest among SIDS. Thus, official development assistance (ODA) for the Maldives could reach up to US\$I,II5O. Not to mention that the Maldives have also trapped in external debts around $40 \%$ of their GDP. At the same time, Fiji is slightly fortunate, though it is expected to fall in GDP by around ro \%. Fiji has fewer external debt than some others SIDS. Nevertheless, it is significant to promote funding at zero interest rates and defer recent debt payments for the SIDS (Coke-Hamilton, 2020).

At this moment, there is a significant job shortage in most SIDS. Prior to a pandemic, the unemployment rate in some SIDS reached $50 \%$ and regrettably, most of the jobless were youth (UN SDG, 2020). International Labor Organization (ILO) describes a condition in SIDS as worrisome. With a travel restriction policy, the SIDS have placed in a critical situation and unbearable consequences. In general, SIDS have lost $77 \%$ of international tourists. That indicates the increase in the unemployment rate in the SIDS (CCSA, 202I). One example, Saint Lucia, which shares $43 \%$ of the total GDP in the tourism sector. Martial (202I) describes the tourism collapses incorporated with the decline in remittances flow have intensified income inequality in Saint Lucia; meaning to say that poor inhabitants are becoming poorer. The job shortage also occurred in Maldives and Fiji, which before the pandemic, have been experiencing skills shortages. The government of Fiji and Maldives have called international development agencies for livelihood diversification and skills upgrading programs.

In terms of a health emergency, the SIDS have successfully contained so far. The infection rate is relatively low due to many factors. As a case study, there have been 6.I6I infections and 28 coronavirus-related deaths in Fiji. While in the Maldives, the number is higher, 74.35I infections and 213 deaths (Worldometers.info, 202I). However, the number of illnesses and deaths cannot do justice the actual emergency in Maldives and Fiji. As previously mentioned, the COVID-I9 crisis has caused large scale economic damage. Since many tourism workers lost their livelihood during the pandemic, migration to home countries or their families became a viable option for workers. Yet, in reality, they do not make it through a decent livelihood as a replacement. The precarious situation in the tourism industry was one of the most salient problems in the SIDS. Women are specifically amongst the vulnerable group that suffers the most in the tourism sector (UNSDG, 2020). First, as typical women in developing countries, they often have to get involved in domestic work while caring for her 
family. Second, most of the women identified as low-skilled workers and low-income in the tourism industry. In the SIDS, the data shows women fulfil more than half in the accommodation as well as the food and beverages sector (ILOstat, 2020). In some countries such as Fiji, Maldives, Kiribati, Mauritius, Tonga, and the Dominican Republic, women have the highest share of unemployment in the food and beverage sectors. Women entrepreneurs have the risk of business bankruptcy in the tourism sector since it is difficult to access financial assistance (Zarrilli \& Aydiner Avsar, 2020).

The fall down in international tourist not only directly affects the tourism-related industry. It is not only hardly impacting airlines, transportation, and accommodation services, but the COVID-I9 pandemic also indirectly attacks agriculture, fisheries and construction in the SIDS. In the tourism collapse, tax revenues have plummeted accordingly. In the end, the fiscal balances and the flow of Foreign Direct Investment (FDI) have also dropped, especially for the small island developing economies (UNDESA, 2020).

The economic vulnerabilities in this COVID-I9 pandemic are interrelated and reinforced by disaster risk and climate crisis. During the pandemic, the Tropical Cyclone Harold in April 2020 caused widespread destruction in Vanuatu, Solomon Islands, Tonga and Fiji. In Vanuatu, many critical infrastructures destroyed; $60 \%$ of schools and $20 \%$ of health facilities reported damage. While in Fiji, more than 2.000 houses were ruined by the cyclone (CCSA, 202I). Multi-hazards thinking is necessary for the recovery and rehabilitation phase due to complex natural and social vulnerability in SIDS. In the disaster after disaster circumstances, it is essential to understand the whole setting and the intricacies (Martinet, 20I9). Therefore, the policy failure can be easily avoided by the policymaker. When it comes to the tourism sector recovery phase, the country with external environmental challenges absolutely needs more time.

Kelman et al. (202I) address the importance of well-being and mental health for research, policy, and action regarding SIDS. The study shows a strong connection between the climate change narrative and mental health. The appearance of additional shocks like pandemic will most likely undermine resident's well-being. For example, in Comoros, where most of the inhabitants living under the poverty line. The condition has been getting worse in the COVID-I9 crisis since there is no mental health policy exist. It is very risky for vulnerable groups such as youth, women, and the elderly since they have multiple burdens and limitations. While in the Maldives, mental health is also one of the primary issues to tackle. Similar to all countries that have applied a lockdown policy, the SIDS take a heavy toll on mental health (UNSDG, 2020).

The application of the lockdown policy has impacted the formal education system. Before the COVID-I9 crisis, many SIDS have been struggling to design equitable education for their inhabitants. Previously, SIDS has pioneered a so-called education for sustainable development (ESD) that help the younger generation to comprehend their environmental challenges (Crossley \& Sprague, 20I4). However, with limited technological resources, many students have no learning access, leaving many students uneducated. Though, education is imperative for future island development. A consolidated effort is necessary to ensure the continuity of education for the targeted group and most disadvantaged children and youth (UNSDG, 2020).

According to the explanation above, there is a wide range of socio-economic impacts caused by the pandemic. In the absence of tourism, many SIDS have a double burden, saving the people from the health collapse and economic downfall. Fiji and Maldives are two examples that can represent most of the SIDS condition during pandemic. The predominant narrative has labelled small island residents as desperate, helpless and vulnerable, but it is worth mentioning that small island residents actually have unique coping mechanisms. Therefore, small island residents could withstand their livelihood amid the crisis. 


\section{COPING STRATEGIES AND GLOBAL RESPONSE}

Many experts predict tourism will be the last sector to be recovered. Learning from the past epidemic took almost two years for tourism to recover and bounce back after the shocks (OECD, 2020). However, seeing the current conditions that are not yet conducive, there is no sign that tourism will be back at normalcy anytime soon (Connell, 202I). If the deep, undermined, and prolonged shock continues, many SIDS will be collapsed. Aside from international collaboration and support, some countries have specific strategies to combat current hazardous event.

The United Nations have launched five pillars of the Recovery Plan that guide countries all over the world (See Fig.2). The heart of every step is "build back better", where people are positioned as a priority. On top of that, economic recovery is addressed, focusing on job protection, small-medium sized enterprises, and informal sectors. This global framework can be implemented by every country based on the country needs and context. In the SIDS, the framework is employed to elevate environmental and social sustainability, e.g., climate crisis, poverty, and livelihood diversification. Thus, when tourism standstill, the dwellers would not lose their livelihood.

As a part of economic response and recovery, some countries in SIDS have managed to undertake some activities to maintain the tourism sector. The Caribbean countries have been actively promoting their tourism and some digitalization programs (Mulder, 2020). The Belize Tourism Board launched "Dear Belize" in May 2020. It is a virtual postcard campaign and competition to inspire future travelers. The winner of that competition will win the prize to travel and stay in Belize for 8 -nights. The digital campaign was followed by a fellow Caribbean country, Aruba, with the "Open for Happiness". The Aruba Tourism Authorities have been updating their travelling policy to gain travelers' interest. However, the revenue from digital movement is not high as expected. Although some sectors (e.g., entertainment, $F \& B$, retail) have successfully shifted into a digital platform, tourism has not received public attention yet (Mulder, 2020; Becker 202I).

Figure 2. Five Pillars of UN Recovery Plan
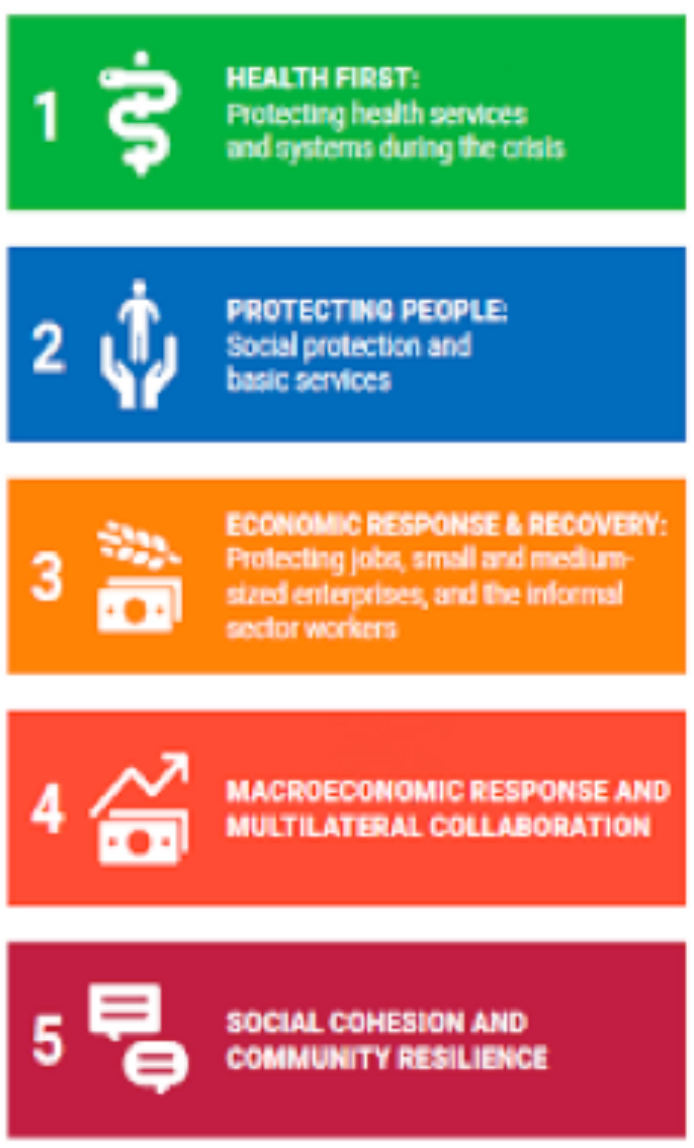

Source: UNSDG, 2020

On the household and individual level, tourism workers have an adaptive capacity against the COVID-I9 crisis through the existing local skills such as farming, hunting in the forest, and traditional fishing (Scheyvens \& Movono, 2020; Walters et al., 202I). Those numerous strategies could reduce the drastic loss of incomes during the lockdown policy. There are at least three arguments that allow local people to survive pandemic: (I) Small island residents still have access to customary land so that they can grow food; (2) A robust social capital and awareness to help the most vulnerable group in the community; (3) local knowledge transmission across a generation that helps younger communities who had lost their job to grow food. Their current income is certainly not as high as when they worked in 
tourism, but they can live subsistence with it (Scheyvens \& Movono, 2020).

In the sudden closure of the tourism sector, some people have quickly found alternative livelihood. The role of the government is crucial to assist people in finding a new livelihood. In some SIDS countries, the government have been actively supporting entrepreneur through social assistance packages and capacity building (Chummun \& Mathithibane, 2020). Therefore, former tourism workers could open their small business such as; food stall, barbershop, crafter, etc. The community in Fiji has demonstrated another coping strategy. Former tourism labors united and together opening a catering business and another form of small-scale business. The community in Fiji mainly uses their natural resources to survive pandemic, thank to well-maintained and well-transmitted local knowledge (Walters et al., 202I). As a side note, the livelihood change in the pandemic time is temporary. People most likely back to work in the tourism sector when the pandemic is over. Yet, the most notable finding is that people have started to aware of their precarity if they only rely on the tourism sector (Becker, 202I). That has also raised discussion about responsible tourism.

The community in the Maldives suggests nature as an essential ally against the COVID-I9 crisis (UN Maldives, 2020). Hence, the government has been focusing on restoring the ecosystem and protecting biodiversity for the health of natural ecosystems. They utilize nature as an integral part for adaptation measures. Besides, the livelihood diversification while maintaining nature is the possible option in the community's ongoing crisis and future recovery phase to have a more alternative source of income. As in other countries, many people in the Maldives have realized the benefit of nature for their subsistence living during the crisis. However, this local strategy rather for short term period.

As mentioned in the beginning, most SIDS are very dependent on international support. Although some people could cope with the uncertain situation, that does not obscure the reality of numerous people under threat.
The international community, through ODA, have provided the bulk of financial aid for SIDS at least US $\$ 2.8$ billion in 2020 (OECD, 2020). That also encompasses new initiatives and regulations to access funding and debt suspension. Bilateral and multilateral cooperation between some developed countries and the SIDS have been extended in order to address infrastructure and technical enhancement.

In terms of the tourism industry, many public and private tourism agencies fill the education gap. They have been actively organizing webinars and training concerning IT and digital skills, entrepreneurship, and digital marketing (Mulder, 2020). The capacity building program is open to the public and especially for tourism workers. Simultaneously, the international community has provided shortterm and long-term measures so-called "blue recovery" to combat the COVID-I9 crisis. It aims to increase the resilience and sustainability of critical sectors as well as economic diversification. The "blue recovery" could be a part of building back better aside from green recovery, which high recognition attention during the COVID-I9 pandemic.

The "blue recovery" measures can be concluded as follows: (I) Addressing SIDS' longstanding debt issues; (2) Embedding sustainability needs and criteria in recovery packages as well as concessional loans; and (3) Supporting SIDS to achieve new, sustainable opportunities, including through new long-term development cooperation schemes, such as international cost-sharing mechanisms for the conservation and sustainable use of ocean assets and techniques to enhance expertise and risk assessment for emerging ocean-related economic activities (OECD, 2020). All in all, the tourism sector recovery has to be embedded in the future development of the SIDS. Furthermore, it should reflect overall Sustainable Development Goals (SDGs), especially SDG I: No Poverty, SDG 3: Good Health, SDG 8: Good Jobs and Economic Growth, and SDG I3: Climate Action. 


\section{REIMAGINE THE FUTURE TOURISM INDUSTRY}

"Tourism can play a key role in a stronger support to the development agenda of the SIDS considering that the sector is the mainstay for the economies of many SIDS, and that, due to their vulnerabilities, the SIDS remain a special case for sustainable tourism development". - Taleb Rifai, Secretary-General, World Tourism Organization (UNWTO)

The debate on the tourism impact has been going on for some years in the SIDS. On the one hand, tourism has been traditionally seen as a labor-intensive sector that creating new employment. In many SIDS countries, tourism has been contributing to GDP that usually indicates economic and welfare impacts. On the other hand, mass tourism in SIDS has caused ecosystem degradation and threatens marine biodiversity. There has been an enormous backlash from NGOs and the community towards a plethora of tourism activities. Interestingly, the COVID-I9 crisis has turned the stakeholder's way of thinking towards tourism (Coke-Hamilton, 2020).

There is an urgency to transform the tourism industry beyond "business as usual" practice. Sustainable tourism has been a buzzword of the SIDS, despite lacking in planning and action. With an absence of tourism revenues, sustainability is no longer a negotiable concept. Most countries have experienced a tremendous unemployment rate and economic depression. Though, some communities still survive with social capital and local knowledge. The pandemic is an opportunity to reimagining the whole island system, from food security, social and political justice, gender equality, education quality, earnings gap, etc. It is a momentum to bring future island to become sustainable and resilient (OECD, 2020).

The findings indicate the abundance of support from international communities to protect island communities. Financial aid and debt suspension are important components to keep SIDS afloat. Those are critical to advance critical infrastructure development, information and technology (IT) capabilities, sustainable productivity growth (Gounder, 2020). However, the tourism sector is full of complexities. The failure to comprehend the intricacies of complex and ever-changing issues will lead to an unsuccessful recovery process. Hence, addressing socio-cultural aspects are pivotal, especially in fragile environmental settings. The livelihood diversification into fisheries and agriculture as implemented in Fiji can be an excellent example for most SIDS.

The tourism stakeholders have been collaborating to empower themselves while waiting for the new normal. They have a distinctive coping mechanism and adaptive capacity to reduce exposure. The change in livelihoods from the tourism sector to nature-based work is intriguing to analyze. In the past, before mass tourism in the Pacific or Caribbean booming, fishing, hunting, and farming were small island residents' livelihood. The relationship between human and nature were heavily increasing in the pandemic. The importance of caring for the environment continues to grow, influencing the tourism regime in SIDS. In this respect, the application of clean technologies (e.g., renewable energy) will be the most practical solution for the tourism industry (Wolf et al., 202I).

The global challenges require a global solution. The pandemic has shaped a new or even reactivating existed global partnership. Every country has a long-term goal to be achieved. So, it is pivotal to keep plans on track amid the disturbance. As an example, Samoa with a "Samoa 2040" vision. The program intends to transform Samoa into a higher growth pathway through investment in critical infrastructure and human capital (UNSDG, 2020). In the COVID-I9 crisis, this original plan was disrupted. Interestingly, the Samoa long-term vision is nearly the same pathway to many SIDS. Therefore, this paper suggests to strengthen the cooperation between SIDS countries along with the international collaboration.

Despite its necessity, it turns out local coping strategies in the SIDS during the pandemic relatively short term. In fact, due to limited resources, the tourism sector in SIDS still cannot be interchangeable and still play significant GDP shares in the SIDS economy. 
So, sustainable tourism practice in the SIDS is undebatable. The COVID-I9 will change the international tourism ecosystems in general. The future of tourism and future island heavily relies on collaborative and responsible governance within the key stakeholders. On top of that, the sustainable tourism sector should be integrated with adaptation to climate change as the most emerging problem. Concerning the future development of SIDS, Robinson (2020) accentuate the identification of more locally appropriate and effective adaptation interventions. Therefore, it can ensure successful adaptation strategies in the future.

\section{CONCLUSION}

Most SIDS have an environmental and socio-cultural predisposition that placed small island communities more vulnerable to the COVID-I9 crisis. As a country with a high dependency on the tourism sector, Fiji and Maldives' downfall can be a glimpse of more adverse impacts of the pandemic in the SIDS. At the same time, the global pandemic also opens up a new avenue for the tourism industry in the SIDS. The policymaker has applied some technical measures namely blue recovery. Apart from practicing sustainable tourism in the future, the long-term programs simultaneously attempt to create livelihood diversification and reduce the adverse impact of the climate crisis and disaster risks. At the individual and household level, the rising awareness towards various benefits of nature indirectly will lessen environmental degradation. In the pandemic, people tend to use available natural resources and maintain them as an alternative livelihood. The phenomenon is almost happening across the world. However, further research needs to be undertaken to understand the genuine positive impact of nature activity in SIDS.

\section{REFERENCES}

Becker, H. (202I). The Impact of the COVID-I9 Global Pandemic on the Cuban Tourism Industry and Recommendations for Cuba's Response. Multidisciplinary
Business Review, I4(I), 7I-83.

Campling, L. (2006). A critical political economy of the small island developing states concept: South-South cooperation for island citizens?. Journal of Developing Societies, 22(3), 235-285.

Chummun, B.Z. \& Mathithibane, M. (2020). Challenges and Coping Strategies of Covid 2019 in the Tourism Industry in Mauritius. African Journal of Hospitality, Tourism and Leisure, 9(5):810-822.

Coke-Hamilton, P. (2020). Impact of Covid-I9 on tourism in small island developing states. Retrieved from https://www. eco-business.com/opinion/impact-ofcovid-I9-on-tourism-in-small-islanddeveloping-states/ [accessed on 20 March 202I].

Committee for the Coordination of Statistical Activities (202I). How COVID-I9 is changing the world: a statistical perspective Volume III. Technical report.

Connell, J. (202I). COVID-I9 and tourism in Pacific SIDS: lessons from Fiji, Vanuatu and Samoa?. The Round Table, IIo(I), I49-I58.

Crossley, M., \& Sprague, T.(20I4). Education for sustainable development: Implications for small island developing states (SIDS). International Journal of Educational Development, 35, 86-95.

Gheuens, J., Nagabhatla, N., \& Perera, E. D. P. (20I9). Disaster-risk, water security challenges and strategies in Small Island Developing States (SIDS). Water, II(4), 637.

Gounder, R. (2020). Economic Vulnerabilities and Livelihoods: Impact of COVID-I9 in Fiji and Vanuatu. Oceania, 90, I07-II3.

ILOstat database (2020). Labour statistic on women. Retrieved from https://ilostat. ilo.org /topics/women/ [Accessed on 26 March 202I].

Kelman, I. (20I4). No change from climate change: vulnerability and small island developing states. The Geographical Journal, I8O(2), I2O-I29. 
Kelman, I. (20I8). Islandness within climate change narratives of small island developing states (SIDS). Island Studies Journal, I3(I), I49-I66.

Kelman, I., Ayeb-Karlsson, S., Rose-Clarke, K., Prost, A., Ronneberg, E., Wheeler, N., \& Watts, N. (202I). A review of mental health and wellbeing under climate change in small island developing states (SIDS). Environmental Research Letters.

Leal Filho, W., Lütz, J. M., Sattler, D. N., \& Nunn, P. D. (2020). Coronavirus: COVID-I9 transmission in pacific small island developing states. International Journal of Environmental Research and Public Health, I7(I5), 5409.

Martial, Z. (202I). What is the impact of COVID-I9 on Small Island Developing States? A Study on Income Inequality in Saint Lucia. Retrieved from https://www. cebm.net/202I/ oI/what-is-the-impactof-covid-I9-on-small-island-developingstates-a-case-study-on-incomeinequality-in-saint-Lucia/ [accessed on 25 March 202I]

Martinet, M. E. (20I9). The disaster after the disaster: The quicksand of post-disaster recovery funding. Journal of business continuity \& emergency planning, I2(4), 33I-34I.

McKibbin, W., \& Fernando, R. (2020). The economic impact of COVID-I9. Economics in the Time of COVID-I9, 45.

de-Miguel-Molina, B., de-Miguel-Molina, M., \& Rumiche-Sosa, M. E. (20I4). Luxury sustainable tourism in small island developing states surrounded by coral reefs. Ocean \& coastal management, 98, 86-94.

Murphy, M. M., Jeyaseelan, S. M., Howitt, C., Greaves, N., Harewood, H., Quimby, K. R., ... \& Hambleton, I. R. (2020). COVID-I9 containment in the Caribbean: The experience of small island developing states. Research in Globalization, 2, Iooorg.

Mulder, N. (2020). The impact of the COVID-I9 pandemic on the tourism sector in Latin
America and the Caribbean, and options for a sustainable and resilient recovery. International Trade series, No. I57 (LC) TS.2020/I47), Santiago, Economic Commission for Latin America and the Caribbean (ECLAC).

OECD (202I). COVID-I9 pandemic: Towards a blue recovery in small island developing states. Retrieved from https://read. oecd-ilibrary.org/view/?ref= I 060 _Io6or74-tnkmsji5ap\&title=COVID-I9pandemic-Towards-a-blue-recovery-insmall-island-developing-states [accesed on 20 March 202I].

Petzold, J., \& Ratter, B. (2019). More than just SIDS: local solutions for global problems on small islands. Island Studies Journal, I4 (I), 3-8.

Pratt, S. (2015). The economic impact of tourism in SIDS. Annals of tourism research, 52, I48-160.

Robinson, S. A. (2020). Climate change adaptation in SIDS: A systematic review of the literature pre and post the IPCC Fifth Assessment Report. Wiley Interdisciplinary Reviews: Climate Change, II (4), e653.

Scheyvens, R. \& Apisalomo M. (2020). Traditional skills help people on the tourism-deprived Pacific Islands survive the pandemic. Retrieved from https:// theconversation.com/ traditionalskills-help-people-on-the-tourismdeprived-pacific-islands-survive-thepandemic-I48987 [accessed on I April 202I].

Suzana, M., Walls, H., Smith, R., \& Hanefeld, J. (2018). Achieving universal health coverage in small island states: could importing health services provide a solution?. BMJ global health, 3(I).

UNCTAD (2020). Impact of COVID-I9 on tourism in small island developing states. Retrieved from https://unctad.org/news/ Impact-covid-I9-tourism-small-islanddeveloping-states [accesed on 20 March 2020].

UNDESA (2020). The COVID-I9 pandemic puts 
small island developing economies in dire straits. Policy Brief No. 64.

UN Maldives (2020). Addressing the SocioEconomic Impact of COVID-I9 on the Maldives. Technical Report.

UNSDG (2020). COVID-I9 Socioeconomic Response and Recovery Framework. Technical Report.

Walters, G., Broome, N., Cracco, M., Dash, T., Dudley, N., Elías, S., ... \& Van Vlietı 3 , N. (202I). COVID-I9, Indigenous peoples, local communities and natural resource governance. PARKS, 27, 57-62.

World Tourism Organization/UNWTO (2020a). Impact assessment of the COVID I9 outbreak on international tourism. Updated December 2020. Retrieved from https://www.unwto.org/impactassessment-of-the-covid-I9-outbreakon-international-tourism [accessed on 20 March 202I].

World Tourism Organization/UNWTO (2020b). UNWTO Briefing Note Tourism and COVID-I9, Issue 2. Tourism in SIDS - the challenge of sustaining livelihoods in times of COVID-I9, UNWTO, Madrid, DOI:https://doi. org/Io.I8III/978928442I9I6.

Worldometers (202I). COVID-I9 Coronavirus Pandemic. Retrieved from https:// www.worldometers.info/coronavirus/ [accessed on 4 April 202I].

Wolf, F., Singh, P., Scherle, N., Reiser, D., Telesford, J., Miljković, I. B., ... \& Kovaleva, M. (202I). Influences of Climate Change on Tourism Development in Small Pacific Island States. Sustainability, I3(8), 4223.

Yin, R. K. (20I3). Validity and generalization in future case study evaluations. Evaluation, I9(3), 32I-332.

Zarilli, S. \& Aydiner-Avsar, N. (2020). COVID-I9 puts women working in SIDS tourism industry at risk. Retrieved from https://unctad.org/news/covid-I9-putswomen-working-sids-tourism-industryrisk. [accessed on 26 March 202I].
Zhang, H., Song, H., Wen, L., \& Liu, C. (202I). Forecasting tourism recovery amid COVID-I9. Annals of Tourism Research, 87 , I03I49.

\section{AUTHOR BIOGRAPHIES}

Abdul Fikri Angga Reksa is a junior researcher in Research Center for Area Studies (P2WLIPI). He obtained a master degree from the University of Bonn and United Nations University (UNU-EHS), majoring in Geography of Environmental Risks and Human Security. His research interest is on climate crisis adaptation and disaster risk reduction.

Ayu Nova Lissandhi is a researcher in Research Center for Area Studies (P2W-LIPI). Her background is in Social Anthropology. She is currently a young researcher within Development, Urban, and Environmental Anthropologist issues. She joined the sustainable development research team from 2010 until 20I8. Ayu can be contacted via email: ayunoor@lipi.go.id or ayu.nls2@gmail. com

Choerunisa Noor Syahid is a researcher in Research Center for Area Studies (P2W - LIPI) Jakarta. She graduated from the Institute for Housing and Urban Studies, Erasmus University Rotterdam, with a Master of Science in Urban Management and Development Studies. Her research interest is urban development issues, such as sustainable cities, smart cities, climate change and its environmental impacts. Public participation and stakeholders engagement is her interests most. 